\title{
Re-charting the Black Atlantic: Jackie Kay's Cartographies of the Self
}

Redéfinir l'"Atlantique noir »: Jackie Kay et les cartographies du moi

\section{Carla Rodríguez González}

\section{(2) OpenEdition \\ 1 Journals}

\section{Electronic version}

URL: http://journals.openedition.org/etudesecossaises/977

DOI: 10.4000 /etudesecossaises. 977

ISSN: 1969-6337

\section{Publisher}

UGA Éditions/Université Grenoble Alpes

\section{Printed version}

Date of publication: 25 April 2015

Number of pages: 103-119

ISBN: 978-2-84310-296-7

ISSN: $1240-1439$

\section{Electronic reference}

Carla Rodríguez González, "Re-charting the Black Atlantic: Jackie Kay's Cartographies of the Self", Études écossaises [Online], 17 | 2015, Online since 25 April 2016, connection on 15 March 2021. URL: http://journals.openedition.org/etudesecossaises/977 ; DOl: https://doi.org/10.4000/ etudesecossaises.977 


\section{Re-charting the Black Atlantic: Jackie Kay's Cartographies of the Self}

In 1993 Cultural Studies scholar Paul Gilroy published his seminal work The Black Atlantic: Modernity and Double Consciousness, a study of the Black diaspora which deconstructs the materialism of the triangular space comprised by the axes of the slave trade in Europe, Africa and America, as well as its influence over contemporary societies. More importantly, Gilroy revises the effect of such traffic of goods and people over the configuration of contemporary Black intellectualism, shifting the attention from the importance of "roots" to that of "routes" in the construction of Black diasporic identities. Gilroy's transcultural and transnational analysis prioritises the Middle Passage as a symbol in its empowering dimension through the metaphor of the ship, a "living, micro-cultural, micro-political system in motion", whose itinerancy facilitates "the circulation of ideas and activists as well as the movement of key cultural and political artefacts: tracts, books, gramophone records, and choirs" (1993, p. 4). While Gilroy's model has received extensive scholarly attention, further analysis have highlighted the shortcomings of his theory, especially concerning issues such as gender, class or the centrality given to certain geographical areas of the Black Atlantic in detriment of others (e.g., Davies, 1994; Oboe and Scacchi, 2008; Evans, 2009; Pinto 2013; Durán-Almarza and ÁlvarezLópez, 2014). The intercultural dynamics at play in Gilroy's study are indeed crucial when analysing the production of Black diasporic artists, yet it also seems necessary to focus on specific contextual circumstances derived from these artists' implicit challenge to local paradigms.

A very clear instance of a literary career that needs to be considered both in relation to a national tradition and a transcultural set of references is that of Scottish writer Jackie Kay, whose contribution to and expansion of the scope of Black Atlantic literature can be traced through her prolific production as a novelist, short story writer, playwright and auto/biographer. Kay's work is the most representative example of wellestablished Scottish multicultural writing, and demonstrates that highquality diasporic texts in the UK are also produced by authors "north 
of the border" (see Macdonald, 2010, pp. 84-6). The aim of this article is, thus, to assess Kay's poetry - in relation to the other genres she has explored - in its local and internationalist dimension, focusing on her contribution to incorporating Scotland into the transnational contemporary literary corpus that addresses and interrogates the Black Atlantic from various angles: political, cultural and emotional. In order to do so, and following Durán-Almarza's conceptualization, Kay's portrayal of the Black Atlantic will be considered as a

[...] geospatial and socio-cultural ever-changing conglomerate, [which] materializes at the intersections of local Atlantic geographies and cultural histories, past and contemporary black diasporic practices and communities, and larger global phenomena, all of them mediated by the play of differencesethnicity, gender, age, class, sexuality, place. (2014, p. 4)

Indeed, Kay has managed to situate Scottish literature in a wide frame of cultural associations through an intense exploration of the self that exceeds both the limits of the writer's individuality and the constrictions of traditional narratives of collective memory. She conjugates the multiple coordinates of her experience in order to imagine a multiplicity of characters and voices by means of which she enacts a strong personal and political agenda. As she declares in an interview with Nancy Gish:

[...] when you write about a Black Scottish woman, you are automatically being political in some way, just because that identity is coming to the fore and you're writing about it, almost irrespective of what you say. Because you're questioning and challenging people's assumptions of what they think of as Black and what they think of as Scottish right away. So I do think of myself as being experimental and challenging in themes. [...] I'm interested in taking different things from Black culture, different Black cultures around the world, and linking them up to my own identity. (2004, p. 179)

Identity and how it is constructed, narrated and performed is crucial in Kay's writing, which often draws from her own experience as a Black woman, a lesbian, and from the fact that she was adopted by white parents and brought up in the city of Glasgow. Kay's literary identities are always intertextual and relational. Her characters and voices develop empowering strategies to fill in the gaps of a fragmented cultural memory by borrowing stories from diverse regions of the Black Atlantic, a practice that Tina Campt and Deborah A. Thomas identify as recurrent in diasporic Black cultures (2008, p. 2).

Jackie Kay's career started in the 1980s, as a Black feminist activist collaborating with different groups of women artists in the framework of what has been defined as the Black British Renaissance, a "complex 
and diverse [movement] in its political and ideological allegiances [which was] united in its commitment to challenging the postwar political consensus on 'race', and popular understandings of what it meant to be 'Black' in British society" (Owusu, 2000, p. 6). Blackness is appropriated as a transnational political concept that simultaneously gathers the transversal experience of racism and the diversity of Black identities. At this stage, some of the most important vindications of the diversity of Black cultures is voiced by associations of Black women, who had, as Alison Donnell contends, "a conscious sense of the need to articulate difference, not just the difference that being a woman makes but also the difference of being Asian, or lesbian, or a poet. Cultural forms began to reflect the need to articulate the multiple imbrications of identity" (2002, p. 14). In this vein, it was essential to find alternatives to white feminist thought and deconstruct the power of Western sisterhood (e.g., see Carby, 1982). Jackie Kay participates in these debates in some of her collective publications, such as A Dangerous Knowing. Four Black Women Poets, by Barbara Burford, Gabriela Pearse, Grace Nichols and Jackie Kay (1984); Charting the Journey. Writings by Black and Third World Women, which she coedited with Shabnam Grewal, Liliane Landor, Gail Lewis and Pratibha Parmar (1988); or Gay Sweatshop. Four Plays and a Company, edited by Osment (1989). This early period is characterized by a profound reaffirmation of her Blackness and feminist ideas (see, for instance, "The Sky Changes Every Second Now" [Grewal et al., 1988, p. 62]), her homosexuality ("Dustbins and Dreams" [pp. 60-1], "Happy Ending" [pp. 56-7] or Remi [pp. 66-7]), together with a strong criticism of Thatcherite politics and racism, both institutionalized and quotidian.

Scotland is always part of the equation, as reflected in some of her most popular poems of this period, such as "Kail and Callaloo", which delves into the contradictions and exceptionality of her hybrid self: "Whit is an Afro-Scot anyway?", "how kin ye be both?" (Shabnam et al., 1988, pp. 195-7). This powerful poem fuses transcultural elements from the Black Atlantic - "Mibbe they wear kilts and wraps / and know that Ymoja / offered yams and fowls"-but the voice is clearly identifiable as Scottish, thus giving this side of her identity supremacy over the rest. Another instance of her early writing is the popular "So You Think I'm a Mule?" (Burford et al., 1988, pp. 53-4), where she portrays an encounter between a young Black girl and an old white woman in a street in Glasgow, who asks a series of discriminatory questions that verbalize her prejudice. ${ }^{1}$ Her "Where do you come from", as Kay has declared

1. Kay has confessed that the inspiration for this poem comes from an incident that happened to her in a pub in London: "I went to sit down on a chair and this woman said 'You cannae sit doon in 
in an interview, is a recurrent question that always implies "you don't belong here": "[e]ither they mean 'Go back to where you came from', or just have this obsessive curiosity that is all the time trying to deny the fact that you're Scottish" (Wilson and Somerville-Arjat, 1990, p. 121). Yet the Black girl's response is far from hesitant, reaffirming both her Scottishness - "I'm from Glasgow" - and her Blackness: "Say, I'm no mating of a she-ass and a stallion no half this and half of that / to put it plainly purely / I am Black." Kay's empowerment as a Black woman is expressed with less ferocity in later publications, for instance in a shorter version of "Where do You Come from", published in the collection of poems Other Lovers and entitled "In My Country", where the girl's anger transforms into indifference towards the old woman's bigotry: "Here', I said, 'Here. These parts." (1993, p. 24) In fact, the rest of her production is characterized by a much more positive portrayal of inter-racial communication, being the first example the acclaimed collection The Adoption Papers (1991), which granted her The Saltire Society First Book Award and The Scottish Arts Council Award. The book is divided in two parts, the eponymous "The Adoption Papers" and "Severe Gale 8", which are counterpoints in Kay's portrayal of a personal and political development: while the first one concentrates on the importance of emotional bonds in the construction of alternative genealogies, the second is highly critical of the social and political situation of the UK in the 1980s: "This was the decade when most lived / in cardboard cities and towns except / those with two massive stone houses" (p. 37). As Alison Lumsden argues, this book shows that "however much identity may be familially (or genetically) constructed, the individual must exist outside the family in an often hostile society which sets its own parameters for the ways in which we are defined" (2000, p. 82).

"The Adoption Papers" has often been considered a "pure" autobiographical text, much to the disapproval of Kay, who has insisted on the liberties she has taken in using some elements from her own experience and adapting them into a literary piece (e.g., see Goodman, 1996; Gish, 2004). The poem examines family relations by focusing on three female voices, the adoptive mother, the biological mother and the daughter, each one represented by a different typography in the book. The poetic reconstruction of each period in the life of the daughter is interfered with by the imagined voices of the other two women, whose feelings are

that chair. That's my chair.' And I said 'Oh, you're from Glasgow, aren't you?' And she said 'Aye, how d'you know that?' And I said 'Oh, I'm from Glasgow myself.' And she said 'You're not, are you, you foreign-looking bugger?' And that response to being Black and Scottish has been one kind of threat that I have had throughout my life. So I decided to write about it in this poem.” (Forbes, 1998). 
incorporated in order to complete the fragments in her narration of her childhood and early adulthood. In fact, in spite of the choral quality of the text, the perspective is always controlled by the daughter in the three sections that give shape to the poem: 1961-1962, 1967-1979 and 1980-1990. In this vein, it is highly significant that the daughter's voice appears in periods where she could not even have a memory of her own. This strategy reinforces Kay's approach, in the sense that it consciously unveils the importance of intertextual participation in the construction of narratives of identity. She plays with the projection of the self in autobiographical texts and creates relational identities where personal history and fiction play complementary roles. Thus, the daughter fuses and then re-renders the stories that she has heard, lived and fantasized about. Such perspective contradicts traditional autobiographies, as so does the chronological fragmentation of the piece-where the first year in the daughter's life, when she would not even have access to language - is prioritized. In this sense, even in chapter four, "Baby Lazarus", where the experiences of the two mothers during the last stage of pregnancy are countered, the daughter's voice intervenes to mark the passing of time: "November", "December", "March" (pp. 16-7). The same happens when the first days after her birth are recreated in chapter two: "On the first night", "On the second night", "On the third night" (p. 13).

The different perspectives on motherhood experienced biologically and through adoption merge in the poem: the adoptive mother idealizes the physical suffering of giving birth, whereas the biological mother refers to it with the same anguish she describes the suspicious gazes she receives from her neighbours, who judge her as a single mother of a mixed-race child. An oneiric component is essential in the poem, especially when the mothers' nightmares and fears are introduced. Two clear instances are chapters four and five, where their obsessions are described, again, from the daughter's perspective. Here, in an attempt to get over the trauma of abandoning her daughter, the biological mother performs a failed burial ritual, after which her baby will return to her as a ghost to fill her mind with a set of obsessions that, again, are imagined by the daughter as an adult woman. On the other hand, the adoptive mother shows different fears, such as those caused by the bureaucratic problems and delays in the process of adoption: "What does she expect? I'm not a mother / until I've signed that piece of paper" (p. 16). At this stage, official documents, such as the birth certificate and the adoption papers, define the social identities of the three women, giving the state institutions the external authority to define their selves and emotions. Nevertheless, the poem constitutes a manifesto in favour of the power of emotions in the construction of genealogies, where personal perceptions of the past 
prevail over the authority of the social, and where the self is conceived of as multiple, intertextual. ${ }^{2}$ The "real" mother, unlike the "imagined" one, accompanies the girl from her childhood into adulthood, helping her through their shared exposure to racism and the complexities of growing up: "Now I come from her, / The mother who stole my milk teeth / ate the digestive left for Santa" (p. 20). Likewise, the daughter, as an adult who has left her homeland, expresses a clear intention to reconstruct a matrilineage of her own, which is transcultural, but again clearly rooted in Scotland:

Here, I am far enough away to wonder-
what were the days like
who were my grandmothers
what were the days like
passed in Scotland
the land I come from
the soil in my blood. (p. 25)

As Carol Camper contends, "[r]ace is an experienced thing. We are part of a race, or races, because experience, history, genetics, physicality, family and politics evidence it" (1994, p. XVIII), and, in Kay's writing, such wide conceptualization does indeed transcend the limits of the family in order to incorporate a series of icons from the Black Atlantic into the cultural genealogy she constructs. In this vein, the daughter in "The Adoption Papers", who has grown up in a predominantly white context, ${ }^{3}$

2. In this sense, Kay explains that she conceives of the self in terms of what she calls "multiplicity", which she defines as "knowing that you can be, that your identity can be, complex, and that you can contain more than one self. [...] When we write, we tap into other selves; we talk into our self at different levels of the conscious mind and the subconscious mind. And I do believe that we do use our subconscious mind to write poetry. [...] Writing is, effectively, scraping the top layer off and going straight to the layer underneath, writing about that and then going to the layer underneath. That process, I suppose, I would describe as multiplicity, finding a way to write about the other selves that we already contain. In a sense, I am my adopted mother, I am my birth mother, I am both these women, and am also myself, and I am also my son. [...] [1] t's just a kind of a sense of continuity, of linking yourself up with the other people that are outside you, but also the people that are inside you, and I think that we do that. Some people have a great sense of their own past, feel that [their family] or people they never met are part of them because they've heard stories about them and because they've got their eyes, their nose, or whatever, and I suppose I've created for myself that sense of identity from not having those things genetically, but from finding other ways to get those things. [...] $[\mathrm{Y}]$ ou don't need genetics or biology to keep close in that very spiritual way in which you can inhabit each other's selves, but you can do it in lots of different ways." (Gish, 2004, pp. 176-7)

3. In her article "Let It Be Told", Kay explains this feeling of isolation further: "[...] being brought up in a very white society, by white parents, and never knowing that the words positive and black could come together made it very difficult to be delighted about it. This is something that I consistently want to bring out in my writing: that when you literally do not know, because you have not seen, any positive black image, then in isolation it is virtually impossible to conjure them up on your own." (1994, p. 534) 
identifies immediately with Black American activist Angela Davis - "[she] is the only female person / I've seen (except for a nurse on TV) / who looks like me" (p. 27). Her identification is principally visual, yet also motivated by the stories that her white adoptive mother tells her about Davis' political achievements. In this way, Kay is highlighting not only the importance of transcultural references in the constitution of the girl's identity, but also how transracial communication and collaboration are possible and have been crucial in her creation of a hybrid self.

With this book, Kay inaugurates a political and aesthetic path that will be explored further in later publications, especially in her complex auto/biography of the American blues singer Bessie Smith (1997). Kay's strategy follows in many respects Audre Lorde's conceptualization of the term "biomythography" (1982), as a textual strategy and method of exploration for ex-centric identities, which conjures the plurality of the self in its interrelational, fluid and fragmented dimension. Bessie Smith - together with Pearl Bailey - is mentioned tangentially in The Adoption Papers, but she will be essential in Kay's personal account of the Black Atlantic. This is not coincidental. Other Black feminists, like the above-mentioned Angela Davis, or Patricia Hill Collins (1991), have explored the role played by the blueswomen in the creation of empowered identities for Black women. In this sense, Bessie Smith is crucial in Kay's representation of identities. It weaves a complex text of references that combines a subjective narration of the singer's life with the account of the life of Kay's literary persona. Unlike traditional auto/biographical texts, where the objectivity of the author is taken for granted, Kay's voice is part of the narration as one more legitimate piece in the puzzle that she is reconstructing, namely, Bessie Smith's life but also her own development as an empowered Black woman and a lesbian. Her participation adopts different perspectives: as a young girl who sees Bessie Smith as a cultural surrogate mother, or as the adult who has gathered the historical sources to write this polyphonic text. Such plurality allows her to deconstruct and fictionalize Smith's life to the point that she even introduces an imagined reconstruction of the singer's voice. Thus, the self is conceived of as relational not only by incorporating close family and acquaintances, but also people from other parts of the world and who have lived in different periods. Kay's facet as a poet is also present in this book, whose first pages include "The Red Graveyard", a poem that is also part of the collection Other Lovers, and whose structure is shaped by the rhythm of the blues, as shown in its first and last stanzas:

There are some stones that open in the night like flowers

Down in the red graveyard where Bessie haunts her lovers. 
There are stones that shake and weep in the heart of night

Down in the red graveyard where Bessie haunts her lovers. (1993, p. 123)

The blues and, more importantly, Bessie Smith's voice, attract the immediate attention of the girl, who is fascinated by the power of her voice. Indeed, in the mind of the adult woman recalling these memories, it becomes much more vivid that her mother's: "Why do I remember her voice and not my own mother's? / Why do I remember the blues?" The identification with the singer also happens on the visual level when the girl sees Smith's photograph on the cover of a record, "Her black face. Her magnificent black face", which evokes the connection established with Angela Davis in The Adoption Papers. Bessie Smith becomes, then, a symbol of the possible transgression of the racialized meanings inscribed on Black women's bodies. Carol Camper defines the blues as "a powerful, defiant, creative expression claiming victory out of oppression" (1994, p. XXII), that is, a genre and a form of cultural legacy available for the Black diaspora. Kay is aware of the manipulation of the blues by the music industry and the commercialization of Black identities implicit in the process, yet she also manifests a clear desire to redefine and re-render her own transnational Blackness as a woman in the frame of this tradition. As Samantha Pinto contends,

Kay fetishizes Smith as a souvenir as much for her exceptionalism as for her representativeness. Kay's engagement with the souvenirs of diasporic legacy posits the simultaneous distance and intimacy of that recurring memory and the aesthetic responses to it that have made up modern black cultural production. (2013, p. 31)

Kay explores this further in the collection Other Lovers, which starts with a section devoted to Bessie Smith. In its first poems, the book acknowledges the legacy left by Black American women, but it also contains others inspired by Kay's experience as a Scot. The readers are invited to join in on an imagined tour on Bessie Smith's Pullman through a racialized US. The route and the rhythm of the trip are marked by natural rhythms - of the seasons, of harvests, cotton, tobacco - but also by the human rhythms of a society in the process of negotiating difference, as witnessed by Smith, "the Empress", in her performances, which are attended by a Black audience with access to consumerism for the first time and who feel immediate identification with the new Black stardom: "Somebody knew them; somebody could see right into their soul" "The Right Season", p. 11). This is also a route through racism. "Even the Trees" opens the collection warning us; "Everything that's happened once could happen again" (p. 9). The poem denounces the tortures inflicted on Black 
people and has clear reminiscences of Billy Holiday's popular song "Strange Fruit" (1939) in its vivid images and powerful denunciation. Yet again, Kay's book does not only criticize it and imagines strategies to fight it back; for instance, in "Twelve Bar Bessie" (p. 15), where the singer is portrayed facing the Ku Klux Klan on her own- "That's what she done. Her voice was cast iron"- and also the Black men in her company who were paralyzed by their fear. Such mythologized depiction of "the Empress" is an invitation for Black subjects to participate in an active process of empowerment and self-definition.

Apart from these transatlantic connections, Other Lovers is deeply rooted in Kay's Scotland. "Watching People Sing" (pp. 16-8) is a transition poem from the American sequence into the rest of the collection. The second part is more realistic and here Kay uses contemporary women's voices to tackle issues such as love, family and an interior representation of national landscapes. This poem is a reflection on collective identity and the importance of emotions in the performance of rituals and the transmission of identity. It recalls a gathering of friends and relatives who sing together Scottish ballads. The voice in the poem belongs to a teenager, who, as the title announces, is incapable of joining in the singing: "I can't sing. All I can do is watch / and clap, and clap, and clap" (p. 16). Her participation is incomplete, although the periodic repetition of such celebration has an effect on her: "Nights with the same songs / growing on the skin like hairs" (p. 17). Her embodied emotions, nevertheless, only become strong enough to appeal to her directly when she hears a friend, Anna, sing Robert Burns' love poem "John Anderson my Jo John". Anna's voice "makes the song mine", the girl declares, thus revealing that what facilitates the identification is the idealization of romantic love extolled in the poem and the association with the emotions that her friend can express and that she hopes she will receive sometime.

Jackie Kay has explored the effect of music on diasporic Black identities in other works. Her novel Trumpet (1998b), which won the Guardian Fiction Prize and the International IMPAC Dublin Literary Award, among many other recognitions, is perhaps the clearest example. The structure of the novel reproduces the rhythms of jazz, as a symbol of freedom and the transmission of cultural legacies. Jazz allows the instruments to play the same song together, but there is enough space for improvisation (see Rodríguez González, 2007). As Kay explains in an interview with Maya Jaggi: “Trumpet's form echoes jazz. There's a solo, with improvisations by people affected by this secret; one refrain made to play different ways. Jazz is fascinating, because it's always fluid, it has the past in it — work songs, slave songs, blues. Jazz is a process of reinventing itself. And race too, is less fixed, more fluid, in jazz. There's a sense in jazz 
being a family" (1998, p. 10). This structure allows Kay to reconstruct the life of Joss Moody, a transgender Black Scottish trumpet player, on his death by a series of characters who relate to him. The novel again delves into the mechanisms of life narratives and uses recurrent issues in Kay's writing, such as adoption, mixed origins and the expression of a transcultural self, but the central conflict - which is left unresolved at the end of the book - is whether Coleman, Moody's son, will be capable of understanding his father's decision to live his life as he wanted to. Coleman has to choose between hating or understanding his father's reasons, but his dilemma is in fact much bigger, because he has to reconstruct this life from the available fragments and give them coherence by incorporating himself and his emotions into this process. In the letter that Moody leaves for his son he says, "It is quite simple: all of this is my past, this is the sum of my parts; you are my future. I will be your son now in a strange way. You will be my father telling or not telling my story" (p. 277), and then concludes, "I'm being silly: remember what you like. I've told you everything. My father came off a boat right enough" (p. 277). In this final section, the "boat", the symbol vindicated in Gilroy's study, is given a central role. This is the only certainty that Coleman will have about his genealogy, the fact that they are part of the Black Atlantic diaspora. Now Coleman has to learn that the gaps in their genealogy can be transformed into spaces of empowerment.

Kay's poetic exploration of Scottishness is also evident in her collection Off Colour (1998), which focuses on what appears described as the historical "malaises" of the nation: racial bigotry, gender discrimination and homophobia. Of particular interest to analyse her articulation of Black diasporic identities are poems like "Hottentot Venus", where she gives voice to Saartjie Baartmann, the nineteenth-century South African slave transported to Europe as an attraction in a freak show, and who was obliged to become a prostitute. Baartmant, who has now become an icon of the struggle against racism, is vindicated in Kay's text, where she speaks in the first person to denounce the atrocities she was exposed to with the complicity of Western science. Another woman that is part of Kay's Black Atlantic is Joy Gardner, an illegal immigrant from Jamaica who died in front of her young son, as she was being arrested by the police to be deported. In Kay's poem, "Teeth", she is not even given a name. Instead, she becomes an anonymous "X", which turns Gardner's death into a collective experience. Besides, Kay expands the geographical boundaries of the Black Atlantic to other parts of the world in poems like "Christian Sanderson", which focuses on the transportation of a Black woman to Australia after stealing a small amount of money to buy food for her daughter. As Alison Lumsden explains, the poem "pro- 
vides a double condemnation of Scotland, suggesting both a history of class injustice [...] and gender discrimination" (2000, p. 86), which is reinforced by the woman's use of Scots in the first person as a strong identity marker. The link with Africa is treated with irony, for instance, in "Pride", which describes a conversation on a train between a Black Scottish woman and a man who seems to recognize in her features a genetic connection with the Ibo ethnicity.

Both her next book of poems, Life Mask (2005), and the short story collection Wish I Was Here (2006) delve into loss, solitude and broken relationships between women, although the exploration of the feelings grown in such situations of crisis are universal. The title, Life Mask, as Kay explains in her introduction, was inspired by her collaboration with other artists, like sculptor Michael Snowdon — who made a bronze head of the author that is now exhibited as part of the twelve herms in Edinburgh Business Park - or painter Joyce Cairns and conceptual artist Helen Chadwick. Kay's "masks", which represent her face, and in a wider sense, her identity, also blur her emotions and reinterpret the expression of her changing self. As Paul de Man would argue in his analysis of life writing, the act of writing is always an autobiographical process that requires the creation of "masks", as signs to represent a self that will never become completely visible, since its complexities and changing nature can never be reproduced by the text, which is, on the other hand, exposed to the interpretation of its readers: "prosopon poien, to confer a mask or a face (prosopon). Prosopopeia is the trope of autobiography, by which one's name $[\ldots]$ is made as intelligible and memorable as a face" (1979, p. 926). De Man uses the metaphor of the dead and the living to refer to the multiplicity of our experience and the différance in the narration of our identities, but also to the representation of our memories, to the distorted recuperation of the past through narrations that are always diegetic. ${ }^{4}$ Kay's masks of identity, as has been discussed, play the same role in the sense that she offers her readers a game of multiple identifications that can never be understood as essentially "true"; we are invited to take part in her construction of alternative selves, whose interpretation will always depend on our subject - and subjective - positioning as active readers.

4. In this sense, de Man contends: "As soon as we understand the rhetorical function of prosopopeia as positing voice or face by means of language, we also understand that what we are deprived of is not life but the shape and the sense of a world accessible only in the private way of understanding. Death is a displaced name for a linguistic predicament, and the restoration of mortality by autobiography (the prosopopeia of the voice and the name) deprives and disfigures to the precise extent that it restores. Autobiography veils a defacement of the mind of which it is itself the cause." (1979, p. 930) 
Life Masks also includes a sequence of poems about Kay's encounter with her biological father in Nigeria, which she has also investigated in the collection of poems Fiere (2011) and the autobiographical narrative Red Dust Road (2010), together with meeting her biological mother in Scotland. These books confirm Kay's portrayal of her genealogy as a chain of conscious selections of what forms part of it and what does not. As Ben Wilkinson remarks, "fiere" means "companion" in Scots, and so Kay's Scottish cultural roots are prioritized in her journey of exploration of her African connections, which are demythologized and simultaneously reconstructed in the mind of the poet. Her African masks are thus, a signifier whose signified is available for the reader to decipher. Masks are part of the strategies we all use to define our identity; for instance, her biological father, a new-born radical Christian, puts "the white mask of God on his handsome face" in "Things Fall Apart" (2005, p. 33), one of the poems that portrays the disappointment of the encounter, and their different expectations about each other, as made obvious by her father's remark: "You are my past sin, let us deliberate on new birth."

In order to analyse Kay's contribution to Black Atlantic literature, it is essential to consider her depiction of slavery and its effects on the lives of Black women in the epic poem/play The Lamplighter (2008), which Kay has described as "a love letter to my ancestors" (2007b). It explores the Atlantic experience from the point of view of four African women, Constance, Mary, Black Harriot and Lamplighter, whose stories are interwoven, together with fragments of historical documents, in order to insist on the necessity to remember their individual stories, which become metonymic as the poem unfolds and we discover its circular structure. In this vein, as Kay has commented, the polyphonic structure of her text was intended "to give the impression that any single story is a multiple one" (2008a, p. 15). The text was written to commemorate the bicentenary of the abolition of the Slave Trade Act and, as Petra Tournay-Theodotu explains, its publication is associated with the proliferation of "neo-slave narratives" by Black British women writers:

[...] with its particular focus on the exploration of slavery and the slave trade through the lens of gender, The Lampligher constitutes a specifically feminist contribution to the corpus of contemporary slave narratives that wish to make an intervention into British memory politics by reminding the country of its imperial past and presenting this legacy as integral to British mainstream history. (2014, p. 180)

Apart from the stylistic differences it shows from other contemporary slave narratives - such as its polyphony or fragmentation — what makes The Lampighter distinct is its emphasis on the historical participation of 
Scotland in the commerce of slaves, principally represented through a character, MacBean, who stands for the discourse of slavery. In this sense, Kay comments,

I was very surprised to discover that slave ships left from Port Glasgow, and that it was the slave trade which allowed Glasgow to reinvent itself-in fact the industrial revolution was partly financed through it. It wasn't black history comfortably in the corner there - it was Scottish history, British history, the history of the world. (2007a)

And in an even more critical tone,

It's time that Scotland included the history of the plantations alongside the history of the Highland clearances. A people being cleared off their land, and taken from the Slave Coast, the Ivory Coast, the Guinea Coast to a new land. Forced to board a ship and taken on a nightmare journey from Hell. (2007b)

Indeed, Scotland's role tends to be diluted into the label "British" in the bibliography on the Black Atlantic. This is also a constant in more traditional discussions of the role played by the country in the slave economies of the Caribbean and North America, which has only recently been challenged by historical and cultural research (see Devine, 2011, pp. 33-4). Scotland's involvement in the Black Atlantic has also been unearthed since 2007, by means of various cultural activities, such as exhibitions, conferences, performances (see Sassi, 2011), which were simultaneously carried out in other parts of the UK. As Chris Weedon contends, such institutionalized projects inevitably suggest a series of questions:

[...] what are the important issues that arise from such initiatives and to what degree might they be seen as effective in creating narratives that allow black British citizens a sense of history, ownership, identity and belonging, while encouraging white Britons to recognise negative dimensions of this history and its legacies in the present. (2008, p. 127)

Whether these commemorations have been successful or not is not the competence of this article to judge, but indeed, and again concentrating on the case of Scottish culture, there are two literary texts that have reshaped the history of Scotland's participation in the Black Atlantic: James Robertson's Foseph Knight (2003), a historical novel about the life of a Black slave who travels to Scotland from Jamaica and eventually becomes a free man, and Jackie Kay's The Lamplighter.

Kay's emphasis is put on the experience of women slaves, whose bodies become battlefields, once they have survived the atrocities of the Middle 
Passage, unlike other companions who are thrown "[i]nto the howling, moaning Atlantic. / Into the open-grave-green sea" (2008, p. 12). In fact, the text constitutes a celebration of survival and a homage to these women's resistance, as symbolized by the light carried by the Lamplighter: "I carried the light to light the lamps / The lamps across the wide dark sea" (p. 42). This light illuminates the spirit of her companions and gives them hope to carry on in any spot of the Black Atlantic where they happen to be transported:

\section{BLACK HARRIOT:}

London, Birmingham, Manchester, Liverpool, Bristol, Glasgow, Edinburgh, Lancaster, Hull.

\section{LAMPLIGHTER:}

I put those cities on the map $[\ldots]$

MARY:

Virginia Street, Tobago Street, Jamaica Street, Ingram Street, Glassford Street. (p. 73)

The Lamplighter denounces that the economic development of the UK in modern times lay on the backs of its slaves, as demonstrated by these examples of place names. Kay encourages her audience to dig out their identity and the identities of those people obliterated in the narration of the past splendour of the country. However, Kay also avoids a Manichean representation of the past by including the efforts of the abolitionist groups, such as one of the first campaigns organized by one of this groups in Glasgow in 1792, when "13,000 residents put their name to a petition drawn from a non-Conformist movement to abolish slavery" (p. 84). In The Lamplighter, Jackie Kay confirms that her writing, as Alison Lumsden has argued, "is characterized by its formal polyphony and its thematic engagement with the vital potentialities of self and identity, [which] reminds us that there can be no single agenda for women's writing" (2000, p. 90). Travelling through Jackie Kay's writing involves a process of deconstruction and redefinition of colonialism and postcolonialism, and taking part in a personal representation of a Black diasporic self that always has Scotland in mind. Present and past times are imagined constantly, in order to interrogate authorized renderings of collective history. She has achieved the difficult task of legitimizing alternative realities in the history of a Black Atlantic that continues to be retold from diverse angles in the minds of her readers. 


\section{Bibliography}

Burford Barbara, Pearse Gabriela, Nichols Grace, and Kay Jackie, $A$ Dangerous Knowing: Four Black Women Poets, London, Sheba, 1988.

Camper Carol (ed.), Miscegenation Blues: Voices of Mixed-Race Women, Toronto, Sister Vision, 1994.

Carby Hazel, "White Woman Listen! Black Feminism and the Boundaries of Sisterhood", in H. S. Mirza (ed.), Black British Feminism. A Reader, London and New York: Sheba, 1997, pp. 5-54.

Camper Carol (ed.), Miscegenation Blues. Voices of Mixed-Race Women, Toronto, Sister Vision, 1994.

Campt Tina and Thomas Deborah A., "Gendering Diaspora: Transnational Feminism, Diaspora and Its Hegemonies", Feminist Review, no. 90, 2008, pp. 1-8.

Davies Carol Boyce, Black Women, Writing and Identity Migrations of the Subject, London and New York, Routledge, 1994.

Davis Angela Y., Blues Legacies and Black Feminism: Gertrude "Ma" Rainey, Bessie Smith, and Billie Holiday, New York, Pantheon, 1998.

Devine T. M., To the Ends of the Earth. Scotland's Global Diaspora 1750-2010, Washington, Smithsonian, 2011.

Donnell Alison, "Nation and Contestation: Black British Writing", Wasafiri, no. 36, 2002, pp. 11-7.

Durán-Almarza Emilia María and Álvarez-López Esther (eds), Diasporic Women's Writing of the Black Atlantic. (En)Gendering Literature and Performace, London and New York, Routledge, 2014.

Evans Lucy, "The Black Atlantic: Exploring Gilroy's Legacy", Atlantic Studies: Literary, Cultural and Historical Perspectives, vol. 6, no. 2, 2009, pp. 255-68.

Forbes Peter (coord.), The Poetry Quartets: 1, London, The British Council / Bloodaxe, 1998.

Gilroy Paul, The Black Atlantic: Modernity and Double Consciousness, London, Verso, 1993.

GisH Nancy, "Adoption, Identity, and Voice. Jackie Kay's Inventions of the Self", in M. Novoy (ed.), Imagining Adoption: Essays on Literature and Culture, University of Michigan Press, 2004, pp. 171-92.

Goodman Lizbeth, "Interview with Jackie Kay", in L. Goodman and J. du Gay (eds), Feminist Stages: Interviews with Women in Contemporary British Theatre, Amsterdam, Harwood Academic, 1996, pp. 251-9.

Grewal Shabnam, KaY Jackie, Landor Liliane, Lewis Gail, and PARMAR Pratibha, Charting the Journey. Writings by Black and Third-World Women, London, Sheba, 1998. 
Hill Collins Patricia, Black Feminist Thought. Knowledge, Consciousness, and the Politics of Empowerment, New York, Routledge, 1991.

JAGgi Maya, "Race and All that Jazz", The Guardian, 5 December, 1998, p. 10.

KaY Jackie, The Adoption Papers, Newcastle upon Tyne, Bloodaxe, 1991.

—, Other Lovers, Newcastle upon Tyne, Bloodaxe, 1993.

__, "Let It Be Told", Kunapipi, vol. 16, no. 1, 1994, pp. 530-44.

_- Bessie Smith, Bath, Absolute Press, 1997.

—, Off Colour, Newcastle upon Tyne, Bloodaxe, 1998a.

—, Trumpet, London, Picador, 1998b.

_- Life Mask, Newcastle upon Tyne, Bloodaxe, 2005.

- Wish I Was Here, London, Picador, 2006.

—, "Interview", The Sunday Times, 27 March 2007a. Available at: <www. nickthorpe.co.uk/journalism/arts/jackie-kay-sunday-times $>$.

—, "Missing Faces", The Guardian, 27 March 2007b. Available at: <www. theguardian.com/books/2007/mar/24/featuresreviews.guardianreview $25>$.

—, The Lamplighter, Newcastle upon Tyne, Bloodaxe, 2008.

- Red Dust Road, London, Picador, 2010.

- Fiere, London, Pan Macmillan, 2011.

Lorde Audre, Zami. A New Spelling of My Name, Watertown, Persephone, 1982.

Lumsden Alison, "Jackie Kay's Poetry and Prose: Constructing Identity", in A. Christianson and A. Lumsden (eds), Contemporary Scottish Women Writers, Edinburgh, Edinburgh UP, 2000, pp. 79-94.

Macdonald Graeme, "Scottish Extractions: 'Race' and Racism in Devolutionary Scotland", Orbis Litterarum, vol. 65, no. 2, 2010, pp. 79-107.

Man Paul de, "Autobiography as De-Facement", $M L N$, vol. 94, no. 5, 1979, pp. 919-30.

PInto Samantha, Difficult Diasporas: The Transnational Feminist Aesthetic of the Black Atlantic, New York UP, 2013.

Овое Annalisa and Scacchi Anna (eds), Recharting the Black Atlantic: Modern Cultures, Local Communities, Global Connections, New York, Routledge, 2008.

Osment Philippe (ed.), Gay Sweatshop Four Plays and a Company, London, Heinemann, 1989.

Owusu Kwesi, Black British Culture and Society. A Text Reader, London and New York, Routledge, 2000.

Rodríguez GonzÁLez Carla, "Biographical Improvisation in Jackie Kay's Trumpet", Scottish Studies Review, vol. 8, no. 1, 2007, pp. 88-100.

SAssi Carla, "Caribbean-Scottish Relations: For a Poetics of Memory", The Bottle Imp, no. 10, 2011. Available at: <www.arts.gla.ac.uk/ScotLit/ ASLS/SWE/TBI/TBIIssue10/Sassi.pdf>. 
Tournay-Theodotou Petra, "Love Letter to My Ancestors': Representing Traumatic Memory in Jackie Kay's The Lamplighter", Atlantis, vol. 36, no. 2, 2014, pp. 161-82.

WheEdon Chris, "Memorialising the Slave Trade in Britain", in R. Valdés Miyares and C. Rodríguez González (eds), Culture and Power. The Plots of History in Performance, New Castle upon Tyne, Cambridge Scholars, 2008, pp. 125-32.

WiLkinson Ben, Review of Fiere, by Jackie Kay, The Guardian, 12 February 2011. Available at: <www.guardian.co.uk/books/2011/feb/12/fierejackie-kay-poetry-review>.

Wilson Rebecca E. and Somerville-Arjat Gillean (eds), Sleeping with Monsters. Conversations with Scottish and Irish Women Poets, Edinburgh, Polygon, 1990. 